\title{
ANNUADIEPOXIDE, A NEW POLYACETYLENE FROM THE AERIAL PARTS OF ARTEMISIA ANNUA ${ }^{1}$
}

\author{
D. MANNS*
}

Pharmazeutisches Institut der Universität Bonn, Kreuzbergweg 26, D-5300 Bonn 1, Germany

and R. HARTMANN

Institut für Physiologische Chemie der Universität Bonn, Nussallee 11, D-5300 Bonn 1, Germany

ABstract.-The aerial parts of Artemisia annua afforded a new highly unstable polyacetylene named annuadiepoxide [1] as well as the known polyacetylene ponticaepoxide [2]. The structures were elucidated by high field nmr techniques.

Artemisia annua L. (Compositae) has for many centuries been considered as one of the most valuable drugs used against malaria in Asia, especially in China (1). In 1971 Chinese chemists (2) isolated artemisinin (Qinghaosu), a sesquiterpene endoperoxide responsible for its reputed medicinal action, from the leafy portions of the plant. Since then $A$. annua has become one of the most extensively investigated plants in recent years.

In a previous paper we reported the isolation and structural elucidation of two new monoterpeneperoxides, $\alpha$-and $\beta$-myrcene hydroperoxide, from the aerial portions of the plant (3). Further studies on the constituents of the aerial parts have led to isolation of a new highly unstable polyacetylene that we have named annuadiepoxide [1] as well as the known polyacetylene ponticaepoxide [2] (4).

After chromatographic purification of the crude petroleum ether extract of $A$. annua by repeated cc two crystalline compounds $\mathbf{1}$ and $\mathbf{2}$ were obtained from the lipophilic portion of this plant. Both are very unstable in the crystalline state when exposed to daylight. The uv spectra of compounds 1 and $\mathbf{2}$ exhibit the characteristic sharp vibrational fine structure spectra of polyacetylenes. From its spectral data, which are identical with those given in the literature $(4,5)$, compound $\mathbf{2}$ was identified as $(E)$-trans-pon-

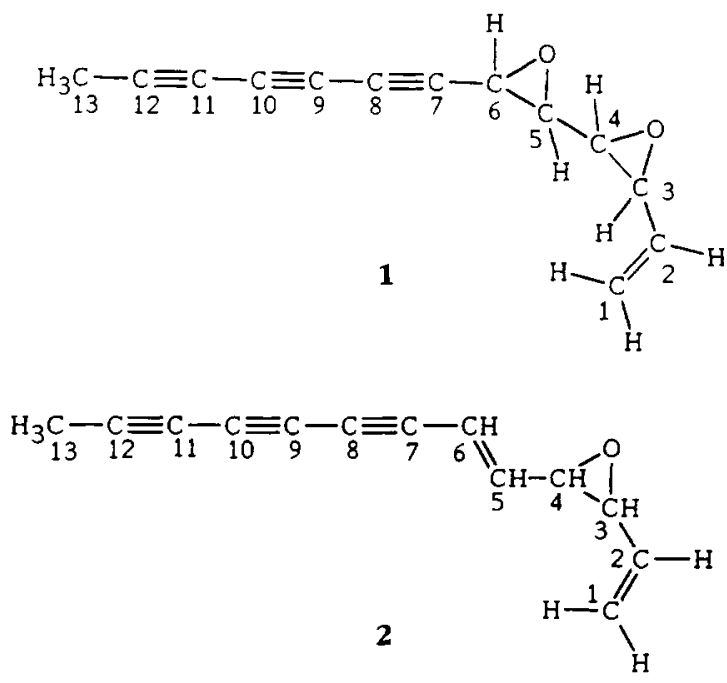

\footnotetext{
${ }^{1}$ Dedicated to Prof Dr. G. Rücker on the occasion of his 60 th birthday.
} 
ticaepoxide. ${ }^{13} \mathrm{C}$-nmr data of compound $\mathbf{2}$, which have not been published until now, are given in Table 1.

Compound 1, which is extremely unstable, shows the typical phenomenon of photodecomposition in the crystalline state and in solution (6). Crystals of $\mathbf{1}$, when exposed to daylight, change their color from white to blue, to brown and finally to black

TABLE 1. ${ }^{13} \mathrm{C}$-nmr Data of Compound 2, $75 \mathrm{MHz}\left(\mathrm{C}_{6} \mathrm{D}_{6}\right)$.

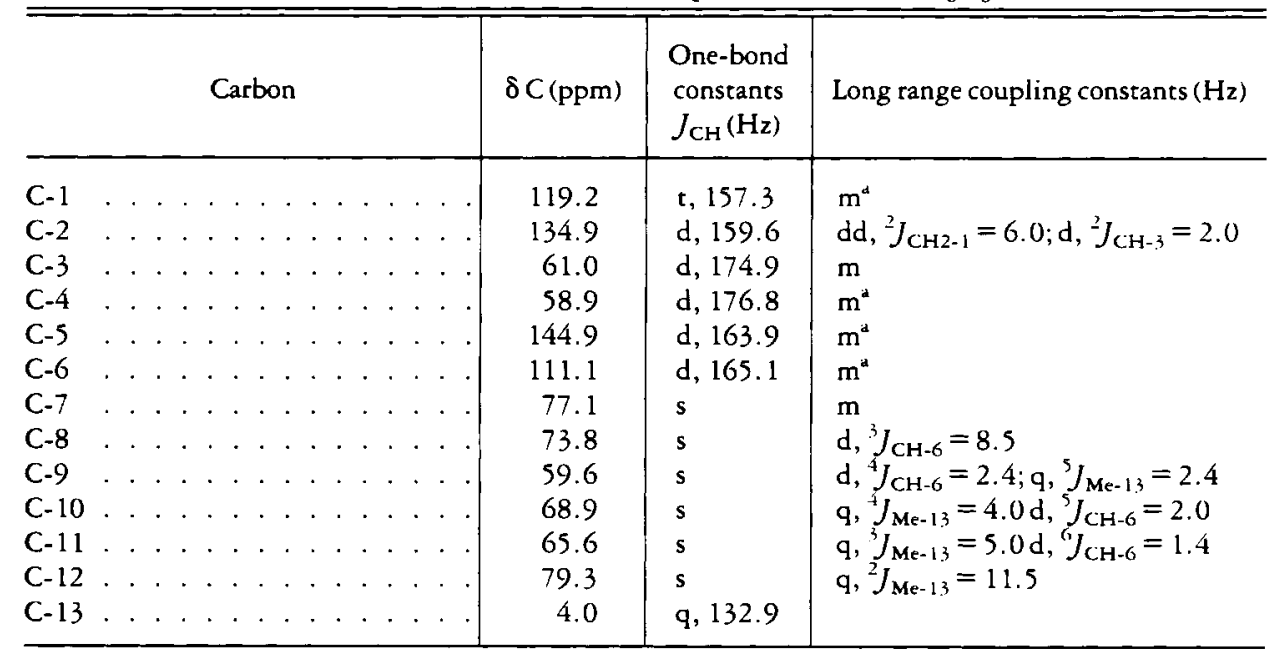

${ }^{\mathrm{a}}$ Multiplet because of higher order systems in the ' $\mathrm{H}$-nmr spectrum.

within a few minutes. The ms of compound 1 shows a molecular ion at $m / z 198$ (3.1\%). The exact mass measurement ( $m / z$ 198.0676) of the molecular ion corresponds to the molecular formula $\mathrm{C}_{13} \mathrm{H}_{10} \mathrm{O}_{2}$ (required 198.0681). Based on this evidence, nine double bond equivalents can be expected. The ir shows bands corresponding to a vinyl group at $3080,1645,985$, and $900 \mathrm{~cm}^{-1}$ and for triple bonds at $2220 \mathrm{~cm}^{-1}$. This is also corroborated by uv maxima. Fine structure, frequency difference ( 7 ), and position of the bands in the uv spectrum $(313,293,276,260,246,215 \mathrm{~nm} ; \Delta v 2180,2102$, 2230 , and $2188 \mathrm{~cm}^{-1}$ ) suggest a triyne without further conjugation. In addition, the ${ }^{13} \mathrm{C}$-nmr spectrum shows six signals for quaternary $\mathrm{C}$ atoms at $78.3,73.7,70.2,65.6$, 65.4 , and $59.6 \mathrm{ppm}$ which, in combination with the long range $\mathrm{CH}$ coupling constants (Table 2) would be expected for a triyne. The $\mathrm{C} / \mathrm{H}$ correlation spectrum (Table 2 ) shows a direct heteronuclear coupling between the three-proton singlet at $1.96 \mathrm{ppm}$ and the

$$
\mathrm{H}_{3} \mathrm{C}-\mathrm{C} \equiv \mathrm{C}-\mathrm{C} \equiv \mathrm{C}-\mathrm{C} \equiv \mathrm{C}-\mathrm{R}
$$

$\mathbf{A}$

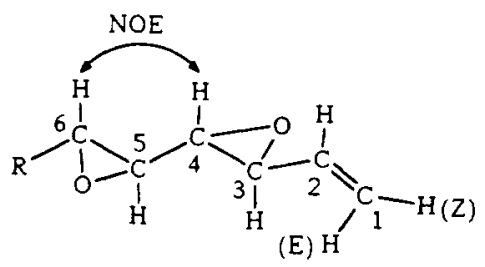


TABLE 2. ${ }^{13} \mathrm{C}$-nmr Data and $\mathrm{C} / \mathrm{H}$ Correlation of Compound 1, $125 \mathrm{MHz}\left(\mathrm{C}_{6} \mathrm{D}_{6}\right)$ and $75 \mathrm{MHz}\left(\mathrm{CDCl}_{3}\right)$.

\begin{tabular}{|c|c|c|c|c|c|}
\hline Carbon & $\begin{array}{c}8 \mathrm{C}(\mathrm{ppm}) \\
\left(\mathrm{CDCl}_{3}\right)\end{array}$ & $\begin{array}{c}\text { Correlated with } \\
\text { H (Table 3) }\end{array}$ & $\begin{array}{c}\delta \mathrm{C}(\mathrm{ppm}) \\
\left(\mathrm{C}_{6} \mathrm{D}_{6}\right)\end{array}$ & $\begin{array}{l}\text { One-bond } \\
\text { coupling } \\
\text { constants } \\
J_{\mathrm{CH}}(\mathrm{Hz})\end{array}$ & Long range coupling constants $(\mathrm{Hz})$ \\
\hline C- 1 & 120.7 & $\mathrm{H}-1(E), \mathrm{H}-1(Z)$ & 120.1 & 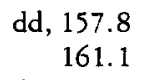 & ? \\
\hline$C-2$ & 133.4 & $\mathrm{H}-2$ & 134.9 & $\mathrm{~d}, 159.9$ & $\tau,{ }^{2} J_{\mathrm{CH}-1}=5.5 ; \mathrm{d},{ }^{2} J_{\mathrm{CH}-3}=2.0$ \\
\hline $\mathrm{C}-3$ & 56.8 & $\mathrm{H}-3$ & 56.8 & $\mathrm{~d}, 176.4$ & $\mathrm{~m}$ \\
\hline$C-4$ & 56.9 & $\mathrm{H}-4$ & 57.3 & $\mathrm{~d}, 178.2$ & $\mathrm{~d},{ }^{2} J_{\mathrm{CH}-3 / 5}=7.6$ \\
\hline$C-5$ & 58.7 & $\mathrm{H}-5$ & 59.2 & $d, 180.7$ & $\begin{array}{l}\mathrm{d},{ }^{2} J_{\mathrm{CH}-4}=6.2 ; \mathrm{d},{ }^{3} J_{\mathrm{CH}-3}=3.0 \\
\mathrm{~d},{ }^{2} J_{\mathrm{CH}-6}=3.0\end{array}$ \\
\hline$C-6$ & 43.4 & $\mathrm{H}-6$ & 43.6 & $\mathrm{~d}, 189.5$ & $\mathrm{~d},{ }^{2} J_{\mathrm{CH}-5}=2.7 ; \mathrm{d},{ }^{3} J_{\mathrm{CH}-4}=2.7$ \\
\hline C-7 & 71.6 & & 73.7 & s & $\mathrm{d},{ }^{2} J_{\mathrm{CH}-6}=5.0 ; \mathrm{d},{ }^{3} J_{\mathrm{CH}-5}=2.5$ \\
\hline C-8 & 69.6 & & 70.2 & $\mathbf{s}$ & $\mathrm{d},{ }^{3} J_{\mathrm{CH}-6}=4.6 ; \mathrm{q},{ }^{6} J_{\mathrm{CH}-5}=2.0$ \\
\hline C-9 & 58.1 & & 59.6 & $s$ & $\mathrm{~d},{ }^{4} J_{\mathrm{CH}-6}=2.0 ; \mathrm{q}, J_{\mathrm{Me}-13}^{5}=2.0$ \\
\hline C-10 & 64.3 & & 65.4 & s & $\mathrm{q},{ }^{4} J_{\mathrm{Me}-13}=3.7 ; \mathrm{d},{ }^{5} J_{\mathrm{CH}-6}=1.8$ \\
\hline C-11 & 64.5 & & 65,6 & $s$ & $\mathrm{q},{ }^{3} J_{\mathrm{Me}-13}=5.0$ \\
\hline C-12 & 77.4 & & 78.3 & $\mathbf{s}$ & $\mathrm{q},{ }^{2} J_{\mathrm{Me}-13}=11.3$ \\
\hline C-13 & 4.6 & $\mathrm{H}-13$ & 4.0 & $\mathrm{q}, 133.1$ & \\
\hline
\end{tabular}

${ }^{\mathrm{a}}$ Multiplet because of higher order systems in the ${ }^{1} \mathrm{H}$-nmr spectrum.

methyl C-13 signal at $4.60 \mathrm{ppm}$. The highfield position of this carbon signal results from a methyl group next to a triple bond. From these facts we suggest partial structure A, hepta-2,4,6-triyne.

The ' $\mathrm{H}$-nmr spectrum (Table 3 ) measured in $\mathrm{CDCl}_{3}$ presents spin systems of higher order. A computer-generated spectrum using the PANIC program (standard software from Bruker) was fitted to the experimentally determined spectrum for the ABX system of the vinyl protons including additional coupling to $\mathrm{H}-3$ with the parameters given in Table 3. Changing the solvent from $\mathrm{CDCl}_{3}$ to $\mathrm{C}_{6} \mathrm{D}_{6}$ results in a clear splitting pattern. In addition to the $\mathrm{ABX}$ system for a vinyl group which appeared at $5.30,5.24$, and $5.06 \mathrm{ppm}$ in the ${ }^{1} \mathrm{H}$-nmr spectrum (Table 3), signals for four methine protons were observed at 2.37 (dd), 2.83 (dd), 2.85 (dd), and 2.96 (d) ppm. The $\mathrm{C} / \mathrm{H}$ correlation spectrum (Table 2) for these methine signals shows correlations for the carbon signals at $43.6,56.8,57.3$, and $59.2 \mathrm{ppm}$. The chemical shifts for these protons and their correlated carbons, together with the appropriate ${ }^{1} J_{\mathrm{CH}}$ coupling constants (Table 2) and the $\mathrm{H} / \mathrm{H}$ correlation spectrum, indicate the presence of two adjacent epoxide rings. De-

TABLE 3. ' ${ }^{\mathrm{H}} \mathrm{H}$-nmr Data and $\mathrm{H} / \mathrm{H}$ Correlation of Compound $1,500 \mathrm{MHz}\left(\mathrm{C}_{6} \mathrm{D}_{6}\right)$ and $300 \mathrm{MHz}\left(\mathrm{CDCl}_{3}\right)$.

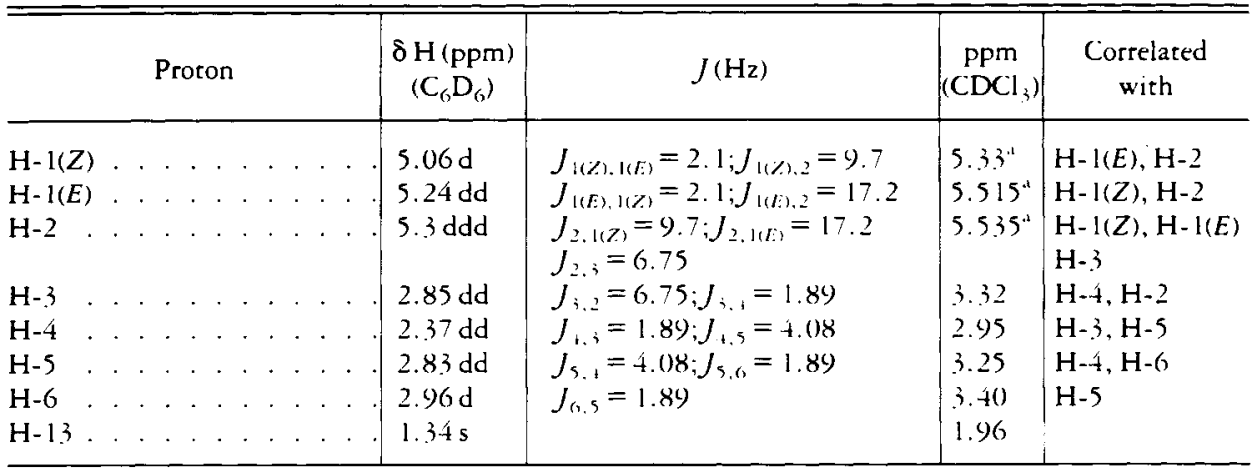

"Calculated by using the PANIC program (standard software from Bruker). 
tailed proton decoupling experiments, in addition to $\mathrm{C} / \mathrm{H}$ and $\mathrm{H} / \mathrm{H}$ correlation spectra, provided evidence for the unusual partial structure $\mathbf{B}$.

The configurations of the epoxy rings were determined using nOe difference spectroscopy. Upon irradiation of $\mathrm{H}-6$ an nOe was observed for $\mathrm{H}-4$; this can only be explained if $\mathrm{H}-5$ and $\mathrm{H}-6$ are in the trans configuration (partial structure $\mathbf{B}$ ). The proton pair $\mathrm{H}-3 / \mathrm{H}-4$ shows a ${ }^{3} J_{\mathrm{HH}}=1.89 \mathrm{~Hz}$ as does the pair $\mathrm{H}-5 / \mathrm{H}-6$; thus both epoxy rings must be in the trans configuration. The carbon skeleton sequence was assigned by a gated decoupled ${ }^{13} \mathrm{C}$-nmr spectrum (Table 2). Accordingly, the overall structure of annuadiepoxide [1] is deduced to be trans, trans-3,4:5,6-diepoxytridec-1-ene-7,9,11triyne (IUPAC name: DL-galacto/DL-ido-3,4:5,6-diepoxytridec-1-ene-7,9, 11-triyne).

\section{EXPERIMENTAL}

General experimental PROCEdures. - Ir spectra were obtained on a Perkin-Elmer model 298 in $\mathrm{CCl}_{4}$. The ${ }^{1} \mathrm{H}$-nmr and ${ }^{13} \mathrm{C}$-nmr spectra were run in either $\mathrm{CDCl}_{3}$ or $\mathrm{C}_{6} \mathrm{D}_{6}$ on Varian $\mathrm{XI} 300$, Bruker AM 400, and Bruker AMX 500 spectrometers. Mass spectra were obtained on a Kratos model MS 50. Uv spectra were run on a Perkin-Elmer model Lambda 2 in hexane.

PLANT MATERIAl. - The aerial parts of $A$, annua were obtained from plants grown from seeds. These seeds were obtained from the Botanic Gardens of the Universities of Frankfurt/Main, Stuttgart/ Hohenheim, and Bordeaux, France. They were planted in a greenhouse and cultivated outdoors. Plants were harvested just before flowering at the beginning of October 1986. A voucher specimen of the plant is preserved at the Herbarium of the Botanical Institute, University of Bonn.

EXTRACTION AND CHROMATOGRAPHIC SEPARATION. -Fresh leaves and flowers of $A$. annua (1.5 $\mathrm{kg}$ ) were extracted with petroleum ether by Ultraturrax extraction. Removal of the solvent under reduced pressure gave $44 \mathrm{~g}$ of a dark green syrup. The crude extract was separated by Hash chromatography (8) on $1235 \mathrm{~g}$ of Si gel using isopropylchloride as the eluent. The fraction with $R_{f}$ values of 0.55 to 0.25 contained ponticaepoxide [2] and annuadiepoxide [1] as the main components. This fraction was evaporated under reduced pressure, giving $2.5 \mathrm{~g}$ of a yellow oil. The yellow oil was chromatographed on a Lobar $\mathrm{C}$ column using $5 \% \mathrm{Et}_{2} \mathrm{O}$ in hexane. Ponticaepoxide $[2](356 \mathrm{mg}, 0.81 \%$ of the extract $)\left(R_{f} 0.3\right)$ and annuadiepoxide [1] (153 mg, $0.35 \%$ of the extract) $\left(R_{f} 0.21\right)$ were obtained as fine white crystals.

DL-galacto/DL-ido-3,4:5,6-diepoxytridec-1-ene-7,9,11-triyne, annuadiepoxide [1]: $\mathrm{ms}(70 \mathrm{eV}) \mathrm{m} / \mathrm{z}$ (\%) $[\mathrm{M}]^{+} 198(3.1), 181(2.4), 169(5.4), 152(3.4), 141(10.6), 139(38.2), 114(9), 100(100), 88$ (11.4), 74 (59.3); uv $\lambda \max$ (hexane) 313, 293, 276, 260, 246, $215 \mathrm{~nm}$; ir $\left(\mathrm{CCl}_{4}\right) 3090,2960,2920$, $2870,2220,1645,1460,1380,985,930,900,875 \mathrm{~cm}^{-1} ;{ }^{1} \mathrm{H} \mathrm{nmr}\left(\mathrm{CDCl}_{3}, 300 \mathrm{MHz} ; \mathrm{C}_{6} \mathrm{D}_{6}, 500 \mathrm{MHz}\right)$ see Table $3 ;{ }^{13} \mathrm{C} \mathrm{nmr}\left(\mathrm{CDCl}_{3}, 75 \mathrm{MHz} ; \mathrm{C}_{6} \mathrm{D}_{6}, 100 \mathrm{MHz}\right)$ see Table 2.

\section{LITERATURE CITED}

1. D.L. Klayman, Science, 228, 1049 (1985), and references cited therein.

2. "Fourth Meeting of the Scientific Working Group on the Chemotherapy of Malaria," Beijing, People's Republic of China, WHO Report TDR/Chemal-SWG (4)/QHS/81.3, p. 5.

3. G. Rücker, R. Mayer, and D. Manns, J. Nat. Prod., 47, 715 (1987).

4. F. Bohlmann, C. Arndt, and H. Bornowski, Chem. Ber., 93, 1937 (1960).

5. G. Kuropka, "Lipophile Inhaltsstoffe aus Acbillea ptarmica L. im Vergleich mit anderen Pflanzen," Ph.D. Thesis, University of Bonn, 1989.

6. F. Bohlmann, T. Burkhardt, and C. Zdero, "Naturally Occurring Acetylenes," Academic Press, London, 1973.

7. K.E. Schulte, Korean J. Pharmacogn., 9, 11 (1978).

8. W.C. Still, M. Kahn, and A. Mitra, J. Org. Chem., 43, 2924 (1978).

Received 28 November 1990 